\title{
When are there substantial reasons to believe that an investigation of core crimes would not serve the interests of justice?
}

\author{
Esperanza ORIHUELA CALATAYUD*
}

\begin{abstract}
The Pre-Trial Chamber II has denied the Prosecutor the request for authorization of an investigation related to alleged war crimes and crimes against humanity committed in Afghanistan. The reason given has been that this investigation would not serve the interests of justice. This paper analyses the practice of the Prosecutor and Pre-Trial Chamber related to this procedure and how they have understood and applied the wording interest of justice, and the changes that this decision has effected. Furthermore, the article includes an evaluation of the decision with reference to some additional question which it raises. These doubts are related to its ultra vires character, its lack of sensitivity to restorative justice, the powers of the Pre-Trial Chamber under Articles 55 and 53 of the Rome Statute, and the use of extra-legal factors in the determination that an investigation does not serve the interests of justice.
\end{abstract}

Keywords: International Criminal Court. Investigation. Authorization to the Prosecutor. Interests of justice.

\section{(A) INTRODUCTION}

On 12 April 2019 the Pre-Trial Chamber II of the ICC rejected the request of the Prosecutor to open an investigation related to Afghanistan'. The principal reason that the Pre-Trial Chamber found to refuse the Prosecutor's request was that this investigation did not serve the interests of justice referred to in Article 53 ı.c) of the Rome Statute.

This is the first time that the Pre-Trial Chamber has refused a request for authorization which may explain why it took so long for the Chamber to announce it'2. In the situation in other places such as Kenya, Côte d'Tvoire, Georgia, and Burundi, the Pre-Trial Chamber always authorized the Prosecutor to investigate, and these decisions did not take more than five months to be announced ${ }^{3}$.

¿s Article published on 31 December 2019

* Professor of Public International Law, University of Murcia.

Public redacted version of "Request for authorization of an investigation pursuant to article I5", 20 November 2017, ICC-02/17-7-Conf-Exp, 12 April, 2019.

2 On 20 November 2017, the Prosecutor requested authorization and the decision, as we know, was adopted on I2 April 2019.

3 In the situation of Kenya, the Prosecutor request authorization on 26 November 2009, and the PreTrial Chamber authorized it on 3I March 20I0; In relation to the situation in Côte d'Ivoire, on 23 June 20II, the Prosecutor filed his request for authorization of an investigation and the Pre- Trial Chamber III gave it on 3 October 2oII. In the situation in Georgia, on 13 October 2or5, the Chamber received the Prosecutor's request for authorization of an investigation and its decision was adopted by the Pre-Trial Chamber I on 27 January 20I6. In the situation of Burundi, on 5 September 20I7, the Prosecutor submitted her request for authorization of an investigation and the Pre-Trial Chamber III decision was adopted on 25 October 2017. 
The decision is related to the proprio motu powers of the Prosecutor to initiate an investigation and to the criteria that he or she has to take into account when deciding whether there is a reasonable basis to investigate or not,

In this article, I will analyse the Prosecutor's practice on proprio motu investigations, and the criteria that he or she uses to determine the existence of a reasonable basis to investigate. In this context, I will focus on the use, meaning, and scope that the Prosecutor and the Pre-Trial Chamber have adopted with regard to "the interests of justice" expression, and how the doctrine has interpreted the dispositions of the Rome Statute. I note that until April 20I9, the Office of the Prosecutor and the Pre-Trial Chamber shared a common idea of the meaning and consideration of the interests of justice and I argue that this consensus has now been broken. I wish to bring to attention the ramifications this disagreement.

\section{(B) BACKGROUND ON PROPRIO MOTU INVESTIGATION ACTIVITIES OF THE PROSECUTOR}

In addition to the referral of a situation by a State or the Security Council, the Prosecutor can receive information from other sources related to the commission of crimes within the jurisdiction of the Court such as organs of the United Nations, governmental and nongovernmental organizations or individuals ${ }^{4}$.

Article I5 of the Rome Statute, which has polemical incorporation in the Preparatory Committee and the Rome Conference ${ }^{5}$, sets out the rules applicable to the exercise on the prosecutor's initiative (proprio motu) of triggering the jurisdiction of the Court. The Prosecutor shall analyse the information (called the preliminary examination), and if he or she concludes that there is a reasonable basis to proceed with an investigation, the Prosecutor will submit to the Pre-Trial Chamber a request for authorization of an investigation $^{6}$. If the conclusion is not to proceed, the Prosecutor shall promptly inform those who provided the information?. This regulation is complemented by Rules 46 to 50 of the Rules of Procedure and Evidence $(\mathrm{RPE})^{8}$.

\section{See regulation 25 of the Regulations of the OTP.}

About the elaboration of Article i5 RS see for example S.A. Fernandez de Gurmendi, "The Role of the International Prosecutor", in R. Lee (ed.), The International Criminal Court: The Making of the Rome Statute: Issues, Negotiations, Results (1999), pp. г75-188; R. Goldstone, N. Fritz, "In the interest of justice and the independent referral: The ICC prosecutor unprecedented power", I3 Leiden Journal of International Law (2000), 655-667, at. 657, and W.A. Schabas, The International Criminal Court. A Commentary on the Rome Statute Second Edition (Oxford, 2016), at. 394-397.

6 See Art. 15.3 RS

7 See Art. 5.6 RS and 49.I RPE that foresees: "Where a decision under article i5, paragraph 6, is taken, the Prosecutor shall promptly ensure that notice is provided, including reasons for his or her decision, in a manner that prevents any danger to the safety, well-being and privacy of those who provided information to him or her under article i5, paragraphs I and 2, or the integrity of investigations or proceedings.

8 Related to the prosecutor's initiative, see H. Olásolo, Corte Penal Internacional: ¿dónde Investigar?Especial referencia a la Fiscaliaen el proceso de activación, Tirant lo Blanch, Valencia, 2oo3; A. 
The recognition of the Prosecutor's trigger capacity would permit work on protecting the interests of the international community but with three essential safeguards. These three conditions are firstly, the submission to the Pre-Trial Chamber of a request for authorization of an investigation; secondly, its authorization; and thirdly, the duty to inform those who provided the information if he or she has concluded that the information provided does not constitute a reasonable basis for an investigation.

The Prosecutor decision considering that there is a reasonable basis to investigate is necessary for every situation, both those referred by States or the Security Council and the proprio motu initiative. Hovewer, its relevance is essential when the Prosecutor request for the authorization of the Pre-Trial Chamber and when his or her decision notes that there is not a reasonable basis to investigate.

If one had thought that the propio motu prosecutor's initiative of triggering the jurisdiction of the Court would be one of the first to start it off, they would have been mistaken. It had to wait seven years from the entry into force of the Rome Statute to receive the first request for authorization and the first affirmative answer of the Pre-Trial Chamber. To date, the Office of the Prosecutor has presented five requests to the Pre-Trial Chamber for authorization of an investigation, and it has considered that there was not a reasonable basis to investigate on other five occasions.

On 26 November 2oog, the Prosecutor Moreno-Ocampo filed a request related to the situation in Kenya9 based on information sent by governmental and nongovernmental organizations, United Nations Funds and Rapporteurs, individuals and groups. In the context of national elections held on 27 December 2007 , this country had suffered an escalation of violence within which crimes against humanity could have been committed, and relevant national judicial enquires had not been undertaken. The Court authorized the Office of the Prosecutor to investigate the alleged crimes committed after I June 20o5, when the Rome Statute came into force in this country ${ }^{10}$.

Two years later, on 23 June 2orr, the Prosecutor applied for authorization to investigate the alleged crimes against humanity committed during the 20IO/2OII post-electoral violence in Côte d'Tvoire". Although this country did not formally ratify the Statute until I5 February 2013, it had accepted the jurisdiction of the ICC by a declaration on I8 April 2003. This statement was confirmed by its President onI 4 December 20 Io and 3 May 201 . It was the first investigation authorized ${ }^{12}$ and opened while a State was not yet a State Party

Tiemessen, "The International Criminal Court and the Politics of Prosecutions". The International Journal of Human Rights, i8 (4-5), 2014, pp. 441-6r; J.N. Foster, "A situational approach to prosecutorial strategy at the International Criminal Court", Georgetown Journal of International Law, 47 (2), 2016, pp. 439-473;

9 ICC-or/o9, 26 November 2009, Public Document Request for authorisation of an investigation pursuant to Article 15.

10 ICC-or/o9-9 Decision Pursuant to Article 15 of the Rome Statute on the Authorization of an Investigation into the Situation in the Republic of Kenya, 3r March 2010.

" ICC-02/II, 23 June 20I, Public Document Request for authorisation of an investigation pursuant to article 15.

12. ICC-02/II-I/4 Decision Pursuant to Article 15 of the Rome Statute on the Authorization of an Investigation into the Situation in the Republic of Côte d'Ivoire, 3 October 20I 
in the Statute but had only accepted the jurisdiction by a declaration provided in Article I2 (3) RS.

The first authorization ${ }^{13}$ and investigation that did not only relate to situations in Africa was initiated on 17 November 20I5. The Prosecutor requested authorization to open an investigation on alleged crimes against humanity and war crimes committed in the context of an international armed conflict between I July and io October 2008 in and around South Ossetia ${ }^{14}$.

Finally, on 15 November 20I7, there was a request for authorization related to Burundir., who deposited its instrument of ratification on 2I September 2004 $4^{16}$. However, this country withdrew its ratification on 26 October 2016, and this decision took effect one year after (Article 127 (I) RS). The Pre- Trial Chamber authorized the Office of the Prosecutor to investigate the alleged crimes within the jurisdiction of the Court committed up to April 2015.

In relation to the preliminary examinations which have been closed, three of those are related to an act of propio motu of the Prosecutor ${ }^{17}$, and the two remaining are situations referred by a State party ${ }^{18}$. The Prosecutor has never closed any of these examinations claiming the investigation does not serve the interests of justice. The most common reason to consider that there is not a reasonable basis to investigate is the non-existence of crimes within the jurisdiction of the Court ${ }^{19}$. The reason given for closure at the preliminary examination related to the situation of the registered vessels of the Union of Comoros, the Hellenic Republic, and the Kingdom of Cambodia was a consequence of the lack of gravity of the crimes committed. This decision has been the only one which has generated a particular controversy between the Prosecutor and the Pre-Trial Chamber, but this has not been related to the interests of justice.

\footnotetext{
13 ICC-or/15-12 Decision on the Prosecutor's request for authorization of an investigation, 27 January 2016.

14 ICC-or/15-4 Corr. 2, I7 November 2015, Public Document with Confidential, EX PARTE, Annexes A, B, C, D.2, E.3, E.7, E.9, F, H and Public Annexes I, D.I, E.I, E.2, E.4, E.5, E.6, E.8, G, I, J Corrected Version of "Request for authorisation of an investigation pursuant to article 15 ", 16 October 2015, ICC-OI/15-4-Corr.

I5 ICC-or/17-5 Red, I5 November 2017 Public with Public redacted Annexes 1 and 8 and Under Seal, EX PARTE, only available to the Prosecution Annexes 2-7 Public redacted version of "Request for authorisation of an investigation pursuant to article 15", 6 September 2017, ICC-01/17-5-US-Exp.

${ }_{16}$ The particular entry into force was on $\mathrm{I}^{\text {st }}$ October 2004.

${ }_{17}$ These are the preliminary examinations related to the first time that the Prosecutor received information on Venezuela, Honduras and Korea.

18 These preliminary examinations are related to Gabon and the registred vessels of the Comoros, Greece and Cambodia.

19 See, Situation in the Republik of Korea, Article 5 Report, June 20r/; Situación en Honduras Informe con arreglo al artículo 5 del Estatuto, Octubre 20r5, and Situation en République gabonaise Rapport établi au titre de l'article 5 du Statut, 2r September 2018.
} 
In this section, I argue that until April 20I9, the practice of the Prosecutor and the PreTrial Chamber in the application of Article $ı 5$ of the Rome Statute has been in only one direction and the interpretation of the wording "interests of justice" has appeared, except to political and legal theorists, quite uniform. This practice has had an influence on the content of the request the Prosecutor presents to the Pre-Trial Chamber.

\section{(1) The position of the Office of the Prosecutor}

How does the Prosecutor determine that there is a reasonable basis to proceed with an investigation? Is it a discretionary decision, or should he or she use specific criteria?

The analysis of the information received, as with every action of the Prosecutor, is conducted according to the general principles of independence ${ }^{20}$, impartiality ${ }^{21}$, and objectivity. These fundamental tenets are common to all international criminal tribunals and their organs.

It is expected that the Prosecutor's decision shall be arrived at after taking into account some additional factors. Rule 48 of the Rules of Procedure and Evidence (RPE) makes a connection between Article 15 and the factors that the Prosecutor shall consider in the decision under Article 53. I of the Rome Statute ${ }^{23}$. This Article refers to some criteria to be taken into consideration in deciding whether there is a reasonable basis to investigate: the crime is within the jurisdiction of the Court; it is admissible, and it is necessary to notes the gravity of the crime and how will this affect the interests of victims. The controversial wording follows the last two criteria because of paragraph (c) avers that "there are nonetheless substantial reasons to believe that the investigation would not serve the interests of justice".

The debate centres on the controversial wording in this paragraph (c) of the Article 53.I

${ }_{20}$ In this context, the independence is understood in the sense of Article 42 of the Rome Statute. The Prosecutor shall act independently of instructions from any external sources. As the Prosecutor notes "(i)ndependence goes beyond not seeking or acting on instructions: it means that decisions shall not be influenced or altered by the presumed or known wishes of any party, or in connection with efforts to secure cooperation." (Policy Paper on Preliminary Examinations 2013, at 7). The Prosecutor is not constrained by the information sent, and he or she may seek information from any reliable sources. On the independence of the Prosecutor, see G. Turrone, Ch. 29.I "Powers and Duties of the Prosecutor, in A. Cassese, P. Gaeta and J. Jones (eds), The Rome Statute of the International Criminal Court, Vol II (Oxford, 2002), II37-II80, at II39-II/3.

${ }_{21}^{2}$ The impartiality involves that no adverse distinction drawn on grounds prohibited under the Statute: gender as defined in article 7, paragraph 3, age, race, colour, language, religion or belief, political or other opinion, national, ethnic or social origin, wealth, birth or other status (art. 2I (3) could be done.

22 The Statute refers to the objectivity in Article $54(\mathbf{I})$ when it regulates the investigation, but this principle and its consequences should apply to the preliminary examinations. This principle is related to establish the true (Policy Paper on Preliminary...., supra n. 20, at 8).

${ }_{23}$ The Rule 48 notes: "In determining whether there is a reasonable basis to proceed with an investigation under article 15, paragraph 3, the Prosecutor shall consider the factors set out in article 53, paragraph I (a) to (c). The link between art. I5 and art. 53 was showed at the Rome Conference had been noted by the Pre-Trial Chamber II, see ICC-OI/o9-I9, paragraphs 22 and 23. 
because it uses an undefined legal concept -the interests of justice- and this lack of definition ${ }^{24}$ is the origin of important disagreements as to its meaning and thus the scope of the discretionary powers of the Prosecutor. Whilst all discussants accept the criteria listed in Article 53, the doctrinal position is polarized. Some authors consider it possible to give a broad sense to this expression, including a variety of considerations other than those strictly related to the criminal proceedings themselves. Others, including the Office of the Prosecutor, defend a narrow meaning and only consider procedural aspects ${ }^{25}$.

In 2007 the Office of the Prosecutor published a Policy Paper on the Interests of Justice to point out that the Afghanistan experience demonstrates that each situation is different, and it is not desirable to establish a fixed relation of factors or circumstances that we should consider in consideration of the interests of the justice issue ${ }^{26}$.

In this paper, the Prosecutor clarifies three interesting aspects. First, there is the presumption in favour of the investigation; second, the object and purpose of the Statute are as a guide to determine the interests of justice in each case; and third, there is a distinction to be made between the interests of justice and the interests of peace ${ }^{27}$. Nonetheless, a decision to not investigate should be considered very exceptional. As the Prosecutor has noted:

"Bearing in mind the objectives of the Court to put an end to impunity and to ensure that the most serious crimes do not go unpunished, a decision not to proceed on the basis of the interests of justice should be understood as a course of last resort. Various other options, besides deciding not to open an investigation or to stop proceedings, may be available". ${ }^{28}$

There is a strong presumption in favour ${ }^{29}$. The prosecutor is not obliged to explain that

24 This expression appears in several places in the ICC Stature and Rules of Procedure and Evidence, but it is never defined.

${ }_{25}$ To know this position, see T. de Souza Dias, "Interest of justice: Defining the scope of Prosecutorial discretion in Article 53 (I) (c) and (2) (c) of the Rome Statute of the Internacional Criminal Court, Leiden Journal of International Law, (2017), 3o, 73 г - 75 г at. 732 and the references to the diferent comentators. She and Dapo Akande are supporter sof the broad meaning, see D. Akande and T. de Souza Dias, "The ICC PreTriasl Chamber Decision on the Situation in Afganistan: A Few Thoughts on the Interests of Justice", ejiltalk, Apil I8 2019 In the same direction, see C. Cárdenas Aravena, "Revisión del criterio "interés de la justicia" como razón para no abrir una investigación o no iniciar un enjuiciamiento ante la Corte Penal Internacional", Revista de Derecho Universidad Católica del Norte, (20II, I), 2I-47, at 34-38. The narrow meaning is also defended by G. Turrone, supra n. 20, at п5 4 , and by Human Rights Watch, Policy Paper: The meaning of "the interests of justice" in article 53 of the Rome Statute June 2005, pp. 20-2I. A broad interpretation but from a human rights perspective is the one defended by Amicus Curiae, see ICC- 02/17- 57, пा July 2019, Amicus Curiae Submissions on Behalf of Human Rights Organizations in Afghanistan, pp. 12-16.

${ }_{26}$ See Policy Paper on the Interest of Justice, September 2007, p.r. The position of the Office of the Prosecutor has been the same until now. See, Policy Paper on Preliminary Examinations, November 2or3, at. 16 and Office of the Prosecutor Policy Paper on Case Selection and Prioritisation, I5 September 2or6, at. 12.

${ }^{27}$ See Policy Paper on the Interest of Justice, supra n. 26, paragraph 67-7.

${ }_{28}$ Ibid., at. 9. The same idea at., Policy Paper on Preliminary Examinations, supra n. 20, at. I6, paragraph 69 and Office of the Prosecutor Policy Paper on Case Selection and Prioritisation, i5 September 20r6, at. 12, paragraph 32

${ }_{29}$ Policy Paper on the Interest of Justice, supra n. 26, p. 3. In the same sense see, ICC- 02/17- 57, II July 2019, Amicus Curiae Submissions on Behalf of Human Rights Organizations in Afghanistan, p. 5.; C. Cárdenas Aravena, supra n. 25, at 24-28; J. Dugard "Posible conflicts of Jurisdiction with Truth Commission", in A 
the required investigation is in the interests of justice. He or she should only furnish an explanation if the investigation would not serve the interests of justice. This affirmation is generally accepted ${ }^{30}$, and it has been the position of the Pre-Trial Chamber. In 20I7, the Pre-Trial Chamber III said:

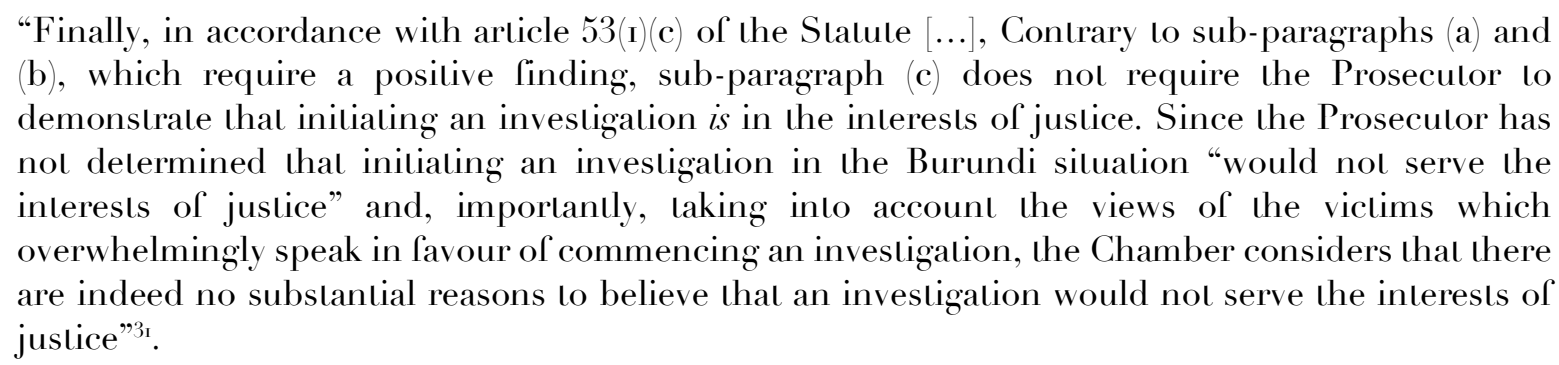

The Prosecutor should take into account the specific factors of Article 53 (I) (c), first the gravity of the crime and the interests of victims, to decide that the investigation would not serve the interests of justice. In respect to the gravity, the Office of the Prosecutor has considered that "(i)n determining whether the situation is of sufficient gravity, the Office considers the scale of the crimes, the nature of the crimes, the manner of their commission and their impact" ${ }^{32}$.

The second factor to consider is the interests of the victims. It is remarkable that at this point in time the Statute makes a reference to the victims. How does the Prosecutor know the interests of the victims if at this point in time there are no official victims? We can imagine that the Prosecutor intends this to refer to taking into account the people and communities named in the preliminary examination.

In general terms, it is likely that the interests of these alleged victims will generally weigh in favour of the prosecution. Nevertheless, in the decision, the meaning of this expression should be related to the position of the victims determined under International Criminal Law, the ICC and the restorative function of the Court. In this sense, the Prosecutor notes that "the central goal of respecting victims through the possibilities of participation in the proceedings also implies a duty to be respectful of possibly divergent views. The Office will give due consideration to the different views of victims, their communities and the broader societies in which it may be required to act". The Office of the Prosecutor also advises that the "interests of victims" include the interest to be

Casesse Comentary, supra n. 9, at 7o; W.A., Schabas, supra, n. 5, at 66o-66ı, and T. de Souza Dias, supra, n. 25 , at 735 .

3o See C. Cárdenas Aravena, supra n. 25, at 24 and 26; J. Dugard, supra n. 29, at 7o and W.A. Schabas, supra, n. 5, at. 66r.

3. ICC-oi/17-X Public Redacted Version of "Decision Pursuant to Article 15 of the Rome Statute on the Authorization of an Investigation into the Situation in the Republic of Burundi”, ICC-01/17-X-9-US-Exp, 25 October 2017, at paragraph igo. See also, ICC-oi/og Decision Pursuant to Article 15 of the Rome Statute on the Authorization of an Investigation into the Situation in the Republic of Kenya, 3г March 20ı,, paragraph. 63; ICCo2/II Decision Pursuant to Article 15 of the Rome Statute on the Authorization of an Investigation into the Situation in the Republic of Côte d'Tooire, 3 October 20I, paragraph 207, and ICC-oI/15 Decision on the Prosecutor's request for authorization of an investigation, 27 January 2017, paragraph 58.

32. See Policy Paper on the Interest of Justice, September 2007, at 5 
protected $^{33}$.

These relatively uncontentious aspects do not appear to be the only circumstances taken into account. To identify what else needs to be considered as relevant it is necessary, as the Procurator notes, to interpret the expression interests of justice "in good faith in accordance with the ordinary meaning to be given to the terms of the treaty in their context and in the light of its object and purpose" ${ }_{34}$. The Preamble of the Rome Statute offers a definition of the purpose of the establishment of the International Criminal Court. His reading reveals that the principal purposes are $\mathrm{I}$ ) to avoid impunity for the most serious crimes of concern to the international community as a whole $\left.{ }^{35} ; 2\right)$ to put an end to impunity for the perpetrators of these crimes and to contribute to its prevention ${ }^{36}$, and 3) to guarantee lasting respect for the enforcement of international justice ${ }^{37}$; in a nutshell, retributive justice which is one of the interests of victims.

Under the umbrella term the interests of justice, the Prosecutor assumes that it is necessary to integrate other strategies or mechanisms to combat the impunity of perpetrators $^{38}$. It is in the context of these interests where some authors pay attention to peace processes, truth commissions, amnesties and their contribution to the interests of justice $^{39}$, and who expand the idea to embrace embryonic democratic process ${ }^{40}$ or future peace and security considerations as well ${ }^{11}$.

33 Ibid. at 5-6.

34 Art. 3I (I) Viena Convention on the Law of Treaties (I969). T. de Souza Dias, supra, n. 25 analyses widely this question, at $735-75$ I.

35 Paragraph four.

36 Paragraph five.

37 Last paragraph.

38 The Prosecutor notes the possible valuation of this factors but as others potential considerations, see Policy Paper on the Interest of Justice, September 2007, at. 7-8.

39 M. Arsanjani, "Reflections on the jurisdiction and trigger mechanism of the International Criminal Court", in Von Hebel, Hermann / Lammers, Johan/ Schukking, Jolien, Reflections on the International Criminal Court, T.M.C. As-ser Press, The Hague, 1999, 57, at 75; F. Bensouda, "Challenges related to investigation and prosecution at the International Criminal Court", in Belleli, Roberto (ed.), International Criminal Justice. Surrey: Ashgate, (20го), г3І, at І1 I; M. Brubacher, "Prosecutorial discretion within the International Criminal Court”. Journal of International Criminal Justice, $\mathrm{N}^{\mathrm{o}}$ 2, 2004, pp. 7I, at 8I; D. Cassel, "Lessons from the Americas: Guidelines for International Response to Amnesties for Atrocities", 59 Law \& Contempo rary Problems (I996) г9г, at 2I3; J. Dugard, "South Africa's Truth and Reconciliation Process and International Humanitarian Law", Yearbook of International Humanitarian Law, 2 (I999), 254-263, at 262263; P. Hayner, "International Guidelines for the Creation and Operation of Truth Commissions: A Prelíminary Propasal", 59 Law \& Contemporary Problems (1996) ı68, at ı73; S. Landsman, "Alternative Responses to Serious Human Rights Abuses: Of Prosecutions and Truth Commissions”, 59 Lax \& Contemporary Problems 75, (I996), at 84; F. Razensberger, The International Criminal Court, Peter Lang, Francfort, 2006, at. I76; M. Scharf, "The amnesty exception o he jurisdiction of the International Criminal Court”. Cornell International Law Journal, No 32, ı999, pp. 5o9, at 524; C. Stahn, "Complementarity, Amnesties and alternative forms of justice: some interpretative guidelines for the International Criminal Court", Journal of International Criminal Justice, $\mathrm{N}^{\mathrm{0}} 3,2005,695$, at $7 \mathrm{I} 9$.

40 See R.J. Goldstone and N. Fritz, supra, n. 5, at 662-663.

4r See ad ex. T. de Sousa Dias, "Interests of justice': Defining the scope of Prosecutorial discretion in Article 53 (I) (c) and (2) (c) of the Rome Statute of the International Criminal Court", Leiden Journal of International Lax, vol 30, 2017, pp. 731-75г, at $745-747$. 
About truth commissions, Goldstone and Fritz note that such an elaboration of the interests of justice could suggest accepting that it would be better that prosecution was not undertaken. These criteria are mostly related to restorative justice ${ }^{4}$, and so it is joined with the interest of victims. However, it is difficult to understand when the intention is to embrace all issues related to peace and security ${ }^{4}$. As the Prosecutor has noted:

“...The Office will consider issues of crime prevention and security under the interests of justice, and there may be some overlap in these considerations and in considering matters in accordance with the duty to protect victims and witnesses under Article 68 . As indicated above, however, the broader matter of international peace and security is not the responsibility of the Prosecutor; it falls within the mandate of other institutions." "xit

As Article 24 (I) of the Charter of the United Nations makes clear, the Security Council has the primary responsibility for the maintenance for peace and security, and the Rome Statute permit to the Security Council to avoid or suspend for a period of twelve months an investigation or prosecution if it is necessary for the international peace and security. Neither the Prosecutor nor the ICC have responsibilities for the maintenance of peace and security unless the interests of victims enforce it.

If the Prosecutor, acting in proprio motu, considers the beginning of the investigation is necessary, he or she will request authorization of an investigation under Article i5 of the Rome Statute to the Pre-Trial Chamber.

In the requests, the Prosecutor has always identified the relevant information, cited its sources $^{45}$ and explained the factors being taken into account to establish a reasonable basis for the investigation, including the jurisdiction and the alleged crimes ${ }^{46}$, the admissibility where the gravity of this criminal conduct is usually noted ${ }^{17}$, and the interests of justice (not elaborated on), confining the analysis to the interests of victims ${ }^{18}$.

The prosecutor also has noted the importance of understanding the situation as a whole and that, at this moment, identification and apportioning of individual criminal responsibility may not be possible. The request takes into account the lower standard used to render his decision, and the Prosecutor argues that there is a reasonable basis to proceed. In his opinion, if the Chamber considers that there is a reasonable basis to proceed with an investigation and that the case appears to fall within the jurisdiction of the Court, "it shall authorize the commencement of the investigation (emphasis added)" ${ }^{9}$.

42 See R.J. Goldstone and N. Fritz, supra, n. 5, at. 663-665.

43 See Policy Paper on the Interest of Justice, September 2007, at. 8.

4 Ibid, at 8-9.

45 ICC-oI/o9, paragraphs 24-44; ICC-o2/II, paragraphs 23-34; ICC-oI/I5 paragraphs 44-5I, and ICC-oI/ı7 paragraphs 32 - I/4I.

$4^{6}$ ICC-oI/o9, paragraph 45-5o and 62-ıог ICC-o2/II, paragraphs 35-43 and 52-253; ICC-oi/ı paragraphs $44-5$ I, and ICC-oI/I7 paragraphs 26-3І.

47 ICC-oI/o9, paragraphs 5i-6i; ICC-02/II, paragraphs 44-58; ICC-oi/s5 paragraphs 274-337, and ICC-oI/I7 paragraphs I/42-195.

48 ICC-oI/o9, paragraphs 6o-6r; ICC-02/ı, paragraphs 59-6o; ICC-oi/ı paragraphs 338-344, and ICCoi/ı paragraphs ig6-ig9.

49 See ad ex ICC-oi/og, paragraphs I02-I03 and ıo6-ıо7, and ICC-o2/II, paragraphs 35-39. 


\section{(2) The Pre-Trial Chamber authorization to investigate}

The prosecutor should behave with complete independence, but he or she is not, in fact, independent because the investigation and prosecution are surrounded by legal obstacles which may paralyze his or her actions. At the outset, there is the need for specific authorization to investigate ${ }^{50}$.

This requirement was the solution adopted by the Diplomatic Conference to get a consensus between states that were defending a propio motu capacity for the Prosecutor and those who considered it was absolutely inappropriate to give the Prosecutor this power, thinking about the real risks of abuse of power and the necessity to prevent arbitrary decisions ${ }^{5 \check{1}}$.

It has been said that the Conference created a Prosecutor "under guardianship" " and the reasons for this control are more political than legal. The Prosecutor's office is not a political organ. It has no a political liability. It is a judicial organ. However, his or her activity could have a meaningful political impact when he or she brings to trial people who have political relevance, and where such decisions might have political consequences.

The Pre-Trial Chamber shall examine the request and the supporting material to consider whether there is, or not, a reasonable basis to proceed with an investigation, and according to the case, he or she shall decide to authorize or refuse. The examination that the Pre-Trial Chamber conducts is of a limited nature, namely to ensure the accuracy of the statement of facts and legal reasons which are at that time presented by the Prosecutor $^{53}$. This function exists essentially to curb any abuse of power, or as the PreTrial Chamber notes "to prevent unwarranted, frivolous, or politically motivated investigations ${ }^{54}$.

The exercise of this kind of control raises some critical question. How does the Pre Trial Chamber adopt its resolution? Is it necessary to use the same criteria that the Prosecutor has used? How deep is the examination of the Chamber? What is the standard of evidence that the Chamber demands? Is a detailed explanation of the decision required?

Article I5 (3) and (4) of the Rome Statute uses the same expression "reasonable basis" to refer to the result of the examination of the Prosecutor and the outcome of the Pre-Trial Chamber, and it is also the expression included in article $53(\mathbf{I})$.

The exercise of a supervisory function must be made using the same criteria that the Prosecutor has used to determine the existence of a reasonable basis to proceed. In its decisions, the Chamber warns that to supervise the proprio motu initiative it must apply

5o The others are related to the Security Council art. I6 RS or States (national investigations, prosecutions or activities included in the proportionality principle art. $\mathrm{I} 7 \mathrm{RS}$.

5. About this question see W.A. Schabas, supra, n. 5, at 394-397 and G. Turrone, supra, n. 20, at II59II6o. A reference to the elaboration of the Article i5 was included by the Pre-Trial Chamber II ICC-oi/o9I9, paragraph 17 and 18 .

5. See G Turrone i9, supra n. 20, at II 42.

53 See S. Fernandez de Gurmendi separate and partially disenting opinion, paragraph 28.

54 See ICC-OI/o9-I9-Corr, paragraph 32; ICC-o2/II-I4, paragraph 2I, y ICC-o2/I7-33, paragraph 3I. 
the same test, or as it stated "the exact standard", that the Prosecutor used ${ }^{55}$, and analyses every criteria taken into account to render a decision about the existence of a reasonable basis to proceed with an investigation. In the decision related to the situation in Kenya, the Chamber has cleared up many questions related to the adoption of the decisions $e x$ Article 15 of the Rome Statute. It defines the "reasonable basis to believe" standard, considering that the request must have relevant available information to suggest that crimes within the jurisdiction have been committed, the admissibility of the cases, the gravity of the crimes, and also the interests of victims. Taking into account these elements, it should then decide whether the investigation would serve the interests of justice or not. In all the previously mentioned situations the Chamber considered that the existence of the four elements had been shown and noted that the investigation will serve the interests of justice. On every occasion, the Prosecutor and the Pre-Trial Chamber have been in agreement that there is a presumption in favour of an investigation.

We need to consider that the information that the Prosecutor has given to the Chamber is the result of a preliminary examination, recalling that it is not conclusive and that it needs only to establish a "reasonable basis to believe".

The use of the words "reasonable basis" suggests that the evidentiary standard will be lower than the three standards established at the Rome Statute ${ }^{56}$. This standard does not, for example, require that the conclusion reached on the facts to be the only possible or reasonable one ${ }^{5_{7}}$. As the Pre-Trial Chamber II notes, "the Chamber must be satisfied that there exists a sensible or reasonable justification for a belief that a crime falling within the jurisdiction of the Court "has been or is being committed". A finding on whether there is a sensible justification should be made bearing in mind the specific purpose underlying this procedure. ${ }^{58}$ Moreover, Article 15 (4) of the Rome Statute notes that the decision of the Pre-Trial Chamber authorizing to proceed an investigation is adopted "without prejudice to subsequent determinations by the Court with regard to the jurisdiction and admissibility of the case." This precautionary clause advises that at this stage only a preliminary and provisional assessment could be possible on jurisdiction and admissibility because at this time there is no investigation and so there is no case to answer.

If the opinion of the Chamber were not conclusive, and it could only establish that there existed a sensible or reasonable justification for a belief that a crime falling within the jurisdiction of the Court has been or is being committed, the Pre-Trial Chamber would grant the authorization. Furthermore, its examination of the material and explanation of its decision would not extend beyond a certain time limit. It is necessary to respect the

55 ICC-oI/og-I9, paragraph 24; ICC-oI/I5-I2, paragraph 4, and ICC-oI/I7-9, paragraph 28.

56 As the Pre-Trial Chamber II said: "(t)he expression "reasonable basis" in Article I5 indicates that a decision to authorize the commencement of an investigation shall be made pursuant to a lower standard than the one required for the issuance of a warrant of arrest or summons to appear." ICC-oI/o9-I9paragraph 102-103.

${ }_{57}$ Ibid. paragraph 33 where the Pre-Trial Chamber makes mention to the Appeals Chamber.

58 Ibid., paragraph 35; ICC 02/II-I/4, paragraph 24; ICC-oı/ı5-12, paragraph 25; 
correct relationship between prosecutorial and judicial functions ${ }^{5_{9}}$.

As I noted before, there exists a presumption in favour of an investigation that does not necessitate a depth analysis by the Pre Trial Chamber of the information presented. As the Prosecutor has said:

"Accordingly, Article I5(4) requires the Pre-Trial Chamber to conduct "an examination of the request and the supporting material". Absent anything to suggest the contrary, the Chamber should conclude that "the case appears to fall within the jurisdiction of the Court". ${ }^{\circ}$

This interpretation and application of Article 53.r of the Rome Statute have two important consequences. First, the Prosecutor only has to explain if he or she believes that an investigation would not serve the interests of justice, and by doing so, this decision triggers the review power of the Chamber ${ }^{61}$. Second, a decision of the Chamber finding that there is not a reasonable basis because the investigation does not serve the interests of justice should be exceptional and should be based on the evaluations that it has made with the criteria of Article 53 (I). This decision cannot be founded upon political criteria because these do not belong to the Court ${ }^{62}$.

\section{(D) THE CHANGE OF THE WAY INTERPRETING THE INTERESTS OF JUSTICE}

As can be seen, the practice of the Prosecutor and the Pre-Trial Chamber in the application of Article 55 of the Rome Statute has been uniform until April 2org. We now come to the exception which proves the rule. The decision of the Pre-Trial Chamber related to the request for authorization of an investigation related to the situation in the Islamic Republic of Afghanistan has changed the factors which the Court must consider when it decided that the investigation would serve, or not, the interests of justice.

\section{(1) What happened on 12 April 2019?}

The Office of the Prosecutor began to receive information relating to the situation in Afghanistan on $\mathrm{I}^{\text {st }}$ June 2006 and it made the preliminary examination public in $2007^{63}$. This country had been involved in armed conflict since r978 when the People's Democratic Party of Afghanistan (PDPA) took power. The pertinent circumstances and acts are those committed in this territory after the first of May 2003 which was when the Rome Statute came into force in Afghanistan ${ }^{64}$.

$5_{9}$ See G. Turrone, supra, n. 20, at. II6r. It is the reason of the partially disidentin opinion of the S. Fernandez de Gurmendi judge, situation in the Republic of Côte d'Tvoire, ICC-oI/II-I5, Corr, paragraphs 3545.

6o See ICC-or/og, 26 November 2009, Public Document Request for authorisation of an investigation pursuant to Article 15, at 39-40, paragraph пाо.

6г In this sense, ICC-or-o9-ı, paragraph 63.

6. See G Turrone, supra, n. 20, at iı6I.

63 See, ad ex, Office of the Prosecutor, Report on Preliminary Activities, i3 December 2oII, paragraph 20. For more information https://www.icc-cpi.int/afghanistan.

64 Afghanistan made its accession on ro February 2003, and Article 126 (2) RS notes that for each State 
Although information started to accumulate with the OTP in 2006, it was not enough to make analysis until the end of $2013^{65}$. The sources of the information, as the Prosecutor noted, have been evaluated following a consistent methodology based on criteria such as relevance, reliability, credibility, and completeness ${ }^{66}$.

On 20 November 20I7, the Prosecutor submitted a request for authorization of an investigation in relation to alleged crimes committed on the territory of Afghanistan in the period since I May 2003, as well as other alleged crimes which relate to the armed conflict in Afghanistan committed on the territory of other States since I July of $2002^{67}$. In her text, Fatou Bensouda uses the same methodology and structure as before. She explains the historical context, the activities made by the OTP, the examination of the information, the crimes which fell within the jurisdiction of the ICC, the admissibility of the case, and last but not least, the question related to the interest of justice. On this point, the Prosecutor explains the gravity of the alleged crimes previously identified and described. She also explains the interests of victims, and she concludes, as she did on previous occasions that: "(i)n the light of the mandate of the Prosecutor and the object and purpose of the Statute, and based on the information available, the Prosecution has identified no substantial reasons to believe that the opening of an investigation into the situation would not serve the interests of justice (emphasis added)"68.

On 12 April 20I9, the Pre-Trial Chamber II adopted a decision pursuant to Article (I5) related to the request of the Prosecutor for an investigation into the situation of the Islamic Republic of Afghanistan ${ }^{69}$.

In this case there are potentially war crimes committed on all sides. There may be war crimes allegedly committed by members of the Afghan National Security Forces (ANSF), together with members of the USA forces and members of the CIA. On the other side there are crimes against humanity and war crimes allegedly committed by members of the Taliban and affiliated armed groups. In all cases their gravity, admissibility, and the interests of victims in seeing justice done would appear to sanction authorization to the investigation. Nevertheless, the Pre-Trial Chamber II decided "that an investigation into the situation in Afghanistan at this stage would not serve the interests of justice and,

acceding to this Statute after the deposit of the $6 \mathrm{o}^{\text {th }}$ instrument of ratification, acceptance, approval or accession (it is the case of Afghanistan), the Statute shall enter into force on the first day of the month after the $6 \mathrm{o}^{\text {th }}$ day following the deposit by such State of its instrument of accession.

${ }_{65}$ ICC-o2/17-7 PUBLIC with confidential, EX PARTE, Anexes 1, 2A, 2B, 2C, 3A, 3B, 3C, 4A, 4B, 4C, 6 public Annexes 4,5 and 7, and public redacted version of Annex 1-Conf-Exp. Public redacted version of "Request for authorization of an investigation pursuant to article 15”, 20 November 2017, ICC-02/17-7-Conf-Exp, paragraph 3.

${ }_{66}$ Ibid, paragraph 29.

${ }^{6}$ ICC-o2/17-33, Public Decision Pursuant to Article 15 of the Rome Statute on the Authorisation of an Investigation into the situation in the Islamic Republic of Afghanistan, I2 April 20I9, paragraph 5.

68 Ibid. paragraph 372.

${ }_{9}$ ICC-02/17-33 12-04-2019, PTC II, Public Decision Pursuant to Article 15 of the Rome Statute on the Authorization of an Investigation into the Situation in the Islamic Republic of Afghanistan 
accordingly, rejects the request" ${ }^{\circ}$. What are the reasons that led the Chamber to decline the Prosecutor's request? The answer to this question obliges to analyse the reasoning behind the decision of the Pre-Trial Chamber. This examination throws up some divergencies in the thinking around the Chamber's previous decisions.

In this decision, the Pre-Trial Chamber explains, as in the four previous situations, that the purpose of the procedure in Article I5 (4) is to prevent the Court from proceeding with unwarranted, frivolous, or politically motivated investigations that could hurt its credibility?. Remarkably, the text of the decision adds a new criterion namely, "to set boundaries to and restrain the discretion of the Prosecution acting proprio motu, in order to avoid manifestly ungrounded investigations due to lack of adequate factual or legal fundaments" (emphasis added $)^{\gamma^{2}}$. It is this new function which permits the Court "to avoid engaging in investigations which are likely to ultimately remain inconclusive" (emphasis added) ${ }^{3}$. Thus, the Chamber, I contend, has removed the discretionary control of OTP to verify a priori the effectiveness of the investigation. Given such an impasse the Chamber believes that investigations would not serve "either the interests of justice or any of the universal values underlying the Statute" 74 , and so there is not a reasonable basis to investigate. This new consideration of predictably inconclusive investigations has fundamental importance.

In their previous decisions, the Pre-Trial Chamber has never considered it necessary to explain that the investigation is in the interests of justice and it has accepted the Prosecutor's position when the victims also agreed with it. In the decision of the Pre-Trial Chamber III on 9 November 20I7, it notes:

\footnotetext{
"(s)ince the Prosecutor has not determined that initiating an investigation in the Burundi situation "would not serve the interests of justice" and, importantly, taking into account the views of the victims which overwhelmingly speak in favour of commencing an investigation, the Chamber considers that there are indeed no substantial reasons to believe that an investigation would not serve the interests of justice" ${ }^{\prime 5}$.
}

By its decision on 12 April 20I9, the Pre-Trial Chamber II appears to have made an I8odegree turn on the interpretation of the interests of justice. This decision notes that the investigation's consistency with the interests of justice is a statutory legal parameter the Chamber should assess. This control must be conducted with care because a partial or inaccurate assessment might have implications for the "objectives of the Statute and hence the overall credibility of the Court, as well as its organizational and financial sustainability" (emphasis added $)^{76}$.

It is surprising that if the Chamber has considered that the consistency of the

7o ICC-02/17-33, at 32 .

7 Ibid., paragraph, 3І.

$7^{2} \quad$ Ibid., paragraph. 32.

$7^{3}$ Ibid., paragraph. 33.

74 Ibid., paragraph. 34.

$7^{5}$ ICC-oI/I7-9-Red, paragraph i9o. See also ICC-oi/o9-ı9, paragraph63; ICC-o2/II-I4, paragraph 2o8, and ICC-OI/ı- 5 - 22, paragraph 58 .

$7^{6}$ ICC-o2/17-33, paragraph 88. 
investigation with the interests of justice is a statutory legal parameter, it did not order to the Prosecutor to provide information about why she has considered that, in this case, there are no substantial reasons to believe that the investigation would not serve the interests of justice 7 . This information might offer some clarifications about the wording of interests of justice.

Related to this question, the decision notes that the determination of the existence of a reasonable basis to investigate must include a positive determination to the effect of that investigation would be in the interest of justice and the likelihood that investigation is feasible and meaningful under the relevant circumstances. ${ }^{8}$ In the opinion of the Chamber, this is difficult in complex situations which have been under preliminary examinations for many years. The Chamber seems to overlook the fact that the accumulation of years of preliminary examinations is a consequence of multiple factors. As such the feasibility and meaning of an investigation is not necessarily dependent on the time expended at this stage. Indeed, the future political environment itself may change. The decision of the Chamber about the existence (or non-existence) of a reasonable basis to investigate is normally based on the information that the Prosecutor has included in his or her request. Never before had the Chamber commented on its quality. In the decision on 12 April 2019, the Chamber considers that it has "to verify whether the notitia criminis is credible and deserves to be assessed and examined further through investigations", and it derives a new criteria to evaluate its reasonableness. This is the "authoritativeness of its source" 79 . In the opinion of the Chamber, United Nations agencies, national organs, and parliamentary inquiry committees have such authority ${ }^{80}$. This appears to throw up a new test. Does it mean that there is no reasonable basis to investigate even if the information brought by the Prosecutor has all its inherent qualities: completeness, relevance, and consistency, but in the opinion of the Chamber the source lacks authority? In the context of the commission of core crimes, which are the most authoritative sources? Are there only credible sources if designated as such by the Chamber? Will the Prosecutor no longer be qualified to make this evaluation?

In the four previous decisions, the Pre-Trial Chamber authorized the investigation when it had determined the existence of a reasonable basis to believe that a crime within the jurisdiction of the Court has been committed; when it had checked the admissibility under Article 17 of the Rome Statute, and when it had taken into account the gravity of the crime and the interests of victims in favour of the prosecution. In its opinion, "there are indeed no substantial reasons to believe that an investigation would not serve the

77 This possibility exists in conformity as Rule 5o (4) of the RPE. In this procedure the Chamber ordered to the Prosecutor to provide additional information in two occasion, on 5 December 2017 and on 5 February 2018.

$7^{8}$ ICC-02/17-33, paragraph 35.

$79 \quad$ Ibid., paragraph 37-38.

so Ibid., paragraph 46 . 
interests of justice" ${ }^{s_{1}}$.

The absence of a definition of interests of justice forces the Pre-Trial Chamber to take into account the relation of these interests with the objectives of the Statute. Thus, there is a new criteria: the requirement for an effective and timely investigation. The Chamber considers now that "an investigation would only be in the interests of justice if prospectively it appears likely to result in the effective investigation and subsequent prosecution of cases within a reasonable time frame" ${ }^{8_{2}}$.

In its opinion, three factors conclusively proved that an investigation of the crimes committed in Afghanistan would not serve the interests of justice, namely: "(i) the significant time elapsed between the alleged crimes and the Request; (ii) the scarce cooperation obtained by the Prosecutor throughout this time, even for the limited purposes of a preliminary examination, as such based on information rather than evidence; (iii) the likelihood that both relevant evidence and potential relevant suspects might still be available and within reach of the Prosecution's investigative efforts and activities at this stage" $"$.

Although the decision does not expressly note it, the Pre-Trial Chamber II uses this interpretation of the interests of justice to influence the selection of cases that has been, de facto, a function of the Office of the Prosecutor. Clarifying this limitation on its scope of action, the Chamber notes that the Court "is not meant -or equipped - to address any and all scenarios where the most serious international crimes might have been committed; therefore, focussing on those scenarios where the prospects for successful and meaningful investigations are serious and substantive is key to its ultimate success" $"$.

The Chamber also wishes to opine on budgetary aspects and considers inappropriate a reallocation of financial and human resources probably to the detriment of other actions of the Court ${ }^{85}$. It must be admitted that it is not easy to find references to material and human resources in the academic analysis of the interests of justice, and when there is some reference, the authors aver that they should not be used as criteria to be taken into account $^{86}$.

Lastly, the Pre-Trial Chamber should consider the interests of victims, and to close the circle that it has drawn, it refers only to the interests of the victims in their participation in the proceedings. If the investigation does not finish, there are no cases before the court, and in the absence of any cases, the victims cannot participate in the proceedings. The Chamber seems to forget that the function of the Court is not retributive only.

\footnotetext{
8ı See ICC-oI/I5-ı2, paragraph 58. In a similar way, ICC- 02/II-I4, paragraphs 2017-208, and ICC-oI/I7-9, paragraph igo.

${ }^{82}$ Ibid., paragraph 89 .

83 Ibid., paragraph 9г.

84 Ibid., paragraph go.

85 Ibid., paragraph 95 .

86 See, Cárdenas Aravena, C, supra n. 25, at 33 with references to other authors as Webb, Behrens, H.J and Gómez Colomer, J.L.
} 


\section{(2) Valuation of the decision}

If the Court had wanted to be the centre of attention, it achieved this. After its decision was published, there was a storm of criticism. It is difficult to find positive, neutral or pragmatic opinions $^{87}$; most of them are severe censures. This decision has been regarded as "a scathing response" 88 , "unfortunate and unwise" ${ }_{9}$ or "unacceptable and shameful" ${ }^{\circ}$ decision. Related to the victims, someone has considered some expressions of the Chamber as "disingenuous" and "paternalistic" ${ }_{9}$. There are also opinions that note the incidence of political reasons in the judges of the Pre-Trial Chamber, and they consider that this decision "relies on a host of non legal factors to explain..." or has succumbed to pressure from the USA Administration ${ }^{92}$. In addition, they comment that this decision came on the heels of the USA revocation of the Prosecutor's visa ${ }^{93}$. Also, some comments focus on the utilitarianism of the position of the Chamber when it seeks to achieve both justice and efficacy ${ }^{94}$, and who inquire if this signals the end of the ICC as we know it ${ }^{95}$.

Whilst all these opinions have merited the opinions related to the legal factors have special importance for us, particularly those related to the interests of justice ${ }^{96}$. The decision of the Pre-Trial Chamber II on 12 April 2019 has been labelled as ultra vires. Jacobs was the first who considered that the Pre-Trial Chamber was not respecting the limits of its functions ${ }^{97}$. I disagree with the reasons he has used to support the power's extra limitation. I do not consider that, when the Chamber decides on authorization, it is limited

$8_{7}$ It could be possible consider as positive the opinion by D. Akande and T. de Souza Dias, "The ICC Pre-Trial Chamber Decision on the Situation in Afghanistan: A Few Thoughts on the Interests of Justice", ejiltalk, published on April ı8, 2019. The web of the American Society of International Law notices only the decision and its support for the interests of justice, https://www.asil.org/ILIB/icc-pre-trial-chamber-rejectsopening-investigation-afghanistan-april-ı2-20Ig (last visit July I6 20Ig). The opinion of Vasiliev considering the decision as the triumph of pragmatism over idealistic (Vasiliev II)

88 See P. Labuda, “A Neo-Colonial Court for Weak States? Not Quite. Making Sense of the International Criminal Court's Afghanistan Decision”, ejiltalk, Published on April ı3, 20I9.

${ }_{9}$ See M. Waraki, "Afghanistan and the "interests of justice"; an unwise exercise?", ejiltalk, Published on April 26, 2019.

$9^{\circ}$ Worldwide Movement for Human Rights (FIDH), Press Release, published on April 12, 20I9, https:/www.fidh.org/en/issues/international-justice/international-criminal-court-icc/icc-refuses-to-

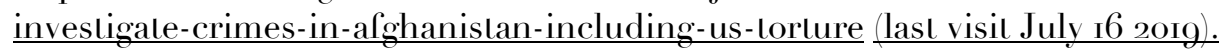

$9^{1} \quad$ S. Vasiliev, "Non just another "crisis": Could the blocking of the Afghanistan investigation spell the end of the ICC? I", ejiltalk, Published on April ı9, 2019.

$9^{2} \quad$ M. Labuda supra, n. 88.

$9^{3}$ B. Walton and A. Farhadi, "The ICC and US Retaliatory Visa Measures: Can the UN Do More to Support the Privileges \& Immunities of the Prosecutor?, ejiltalk, Published on April 23, 2019.

94 Worldwide Movement for Human Rights (FIDH), supra, n. $9^{\mathrm{o}}$.

$9^{5}$ S. Vasiliev, "Non just another "crisis": Could the blocking of the Afghanistan investigation spell the end of the ICC? I and II", ejiltalk, Published on April ig and 20, 20r9.

$9^{6}$ Other reason suggested by some critical commentaries is related to the limitations that the Pre-Trial Chamber considers that it can enforce on the Prosecutor's investigation.

97 D. Jacobs, "ICC Pre-Trial Chamber rejects OTP request to open an investigation in Afghanistan: some preliminary thoughts on an ultra vires decision", Post on April 12 2org. This post could be read in the web: https://dovjacobs.com/20I9/o//2/icc-pre-trial-chamber-rejects-otp-request-to-open-an-investigation-inafghanistan-some-preliminary-thoughts-on-an-ultra-vires-decision/ (last visit October 3I 20Ig). 
by the references on Article $\mathbf{5}(4)^{9^{8}}$, and it is not possible to consider the interests of justice because the Chamber uses the same test or standard as the Prosecutor ${ }^{99}$. I consider the decision of the Chamber ultra vires for another reason. In my opinion, when the Chamber uses efficacy as a criterion to decide an authorization to investigate, it is exercising a right to select and prioritize cases, and also a right to exercise financial control of the budget of the Office of the Prosecutor, and these are not rights or functions of the Pre-Trial Chamber.

It is relevant that the criteria used by the Chamber are found in the Policy Paper on Case Selection and Prioritisation, published by Office of the Prosecutor on 15 September 2or6. As operational criteria, the Office considers, for example, the quantity and quality of the incriminating and exonerating evidence already in the possession of the Office, as well as the availability of additional evidence and any risks to its degradation; international cooperation and judicial assistance to support the Office's activities; the Office's capacity to effectively conduct the necessary investigations within a reasonable period of time, and the potential to secure the appearance of suspects before the Court, either by arrest and surrender or pursuant to a summons ${ }^{100}$.

Judge Mindua in his concurrent and separate opinion explains why they use these operational criteria ${ }^{\text {ior }}$, but not why they should consider them as elements of the interests of justice. The judge and the Chamber are confusing the evaluation of the interests of justice with the selection and prioritization of cases, and they are discrete decisions with distinct functions and operate at different stages of the process. When the Chamber decides on authorization to open an investigation, it should use the same standard as the Prosecutor and not different criteria ${ }^{\text {102 }}$.

The decision on 12 April 2019 has another aspect related to the restorative justice that should be criticised ${ }^{103}$. The Pre-Trial Chamber considers that the failure of the

$9^{8} \quad$ Ibid. In opinion of this author: "The only job of the PTC when the Prosecutor requests the opening of an investigation is to determine jurisdiction and admissibility. And the "interests of justice" fall under neither of these categories".

99 Judge Mindua considers that the Pre-Trial Chamber has competence to analyse the question of the interests of justice. See, ICC-02/17-33 Anex, paragraph I7-23.

100 See Office pof the Prosecutor, Policy Paper on Case Selection and Prioritisation, 55 September 20i6, paragraph 5ı.

Ior As the judge notes: "This idea of taking 'extra-legal' factors into account is also accepted by the ICC Prosecutor in her 'Policy Paper on Case Selection and Prioritisation', published on i5 September 20ı6. She said that she would consider factors such as the availability of international cooperation and judicial assistance to support her activities, her Office's capacity to effectively conduct the necessary investigations within a reasonable period of time, including the security situation in the area, and the potential to secure the appearance of suspects before the Court... As such the feasibility of an investigation is not a separate factor under the Statute when determining whether to open an investigation." ICC-o2/17-33 Anex., paragraph. 4I.

${ }_{102}$ It is always the opinion of the Pre-Trial Chamber, see, ICC-oI/og-I9, paragraph 24; ICC-oI/I5-I2, paragraph 4, and ICC-oI/I7-9, paragraph 28.

${ }^{103}$ On this issue Amicus Curiae Organizations and the Office of Public Counsel for Victims have insisted. See ICC-02/17-55, 25 June 20r9, Request Seeking Leave to File Amicus Curiae Submissions on Behalf of 
investigation could create "frustration and possibly hostility vis-à-vis the Court" in the victims because they will not have the opportunity to participate in the relevant proceedings. Has the Chamber forgotten that the interests of victims are also vested in protection and reparation? We could be forgiven for thinking this if it were not for the opinion of judge Mindua ${ }^{104}$; thus, it is evident that the Chamber knew that opening an investigation is necessary to establish a situation, and this is required to identify victims. For example, the victims of crimes committed in Afghanistan cannot access the assistance of the Trust Fund for Victims because there is no situation. People who suffer torture and cruel treatment, victims of sexual violence, or children conscripted or enlisted under the age of 55 years and who have been used actively in hostilities do not have the assistance of a program to provide physical and psychosocial rehabilitation. Does not this outcome create frustration and hostility from victims vis-à-vis the Court? Does not it have a negative impact on the ability of the Court to pursue restorative justice?

It is surprising that a judge says that "(d)eciding these kinds of investigations without taking into account all relevant factors is irresponsible and would only result in undermining the Court's credibility in the long run, even though such authorisations may satisfy human rights activists and some victims at present." ${ }^{105}$. The judicial decision has at its root, to be just, and it should not need to satisfy any organization or government.

In addition to this assessment, it should be noted that the decision of the Pre-Trial Chamber has raised some questions, the answer to which will be decisive for the Court itself and for the future of the investigations that the Prosecutor deems appropriate to initiate proprio motu. Some of these issues relate to the competence and powers of the Chamber in the proceedings for authorization; others to the factors to be taken into account in the decision relating to the interests of justice; and finally, there are doubts relating to the scope of the authorization granted by the Chamber to the Prosecutor. For us and for this work, the first two are the ones that will be analysed ${ }^{106}$.

The decision on 12 April has brought changes which give rise to doubts as to the powers of the Chamber under Articles I5 and 53 of the Rome Statute. Must the Pre-Trial Chamber make always a determination to the effect that investigation would serve the interests of justice? Must the Pre-Trial Chamber review the decision of the Prosecutor considering the

Human Rights Organizations in Afghanistan and ICC-02/17-59, I2 July 20r9, Submission in the general interest of the Victims on the Prosecutions Request for Leave to Appeal the "Decision pursuant to Article I5 of the Rome Statute on the Authorisation of an Investigation into the situation in the Republic of Afghanistan (icc-02/17-34).

${ }^{104}$ The paragraph 56 of the opinión of judge Mindua notes that the Chamber was aware of the consequences for the victims.

1ог Ibid., paragraph 49 .

${ }_{106}$ The decision of the Pre-Trial Chamber II has raised some doubts about the scope of the authorization; for example, whether the Chamber may authorize the investigation only to incidents identified by the Office of Prosecutor or whether it may even restrict such incidents to those comprised within the authorisation's geographical, temporal, and contextual scope. On this subject see also ICC-02/17-33 Annex Concurring and separate opinion of judge Antoine Kesia-Mbe Mindua, on 3г May 20I9, paragraph 4-ı5. 
investigation would be in the interests of justice? And in this case, has the Chamber the obligation to ask the Prosecutor about this question? The first two questions lend themselves to discussion, but it seems indisputable that if the Prosecutor did not explain that the investigation would serve the interests of justices ${ }^{107}$ because of every single factor points in that direction, the Pre-Trial Chamber must give the Prosecutor the opportunity to be heard on the interests of justice. Likewise, I could extend this question to the victims. Must the Pre-Trial Chamber hear the victims before deciding not to authorise the Prosecutor investigation? Rule 5o (4) RPE provides for the possibility to consult victims and, although it does not oblige the Chamber to do so, it is certainly advisable to.

The Pre-Trial Chamber II has enlarged on factors under Article 53 about the interests of justice. It is necessary to clarify whether the Chamber has discretionary powers to select factors and if in this case, the choice was made correctly.

The use of extra-legal factors makes it possible to consider their consistency with the interpretation of wording interests of justice. Is the degree of the cooperation of the States a relevant factor in determining whether the investigation would serve the interests of justice? Is the scope of the information and evidence gathered so far essential to consider that the investigation would not serve the interests of justice? Is the belief that the investigation will be unfeasible or that the Prosecutor should allocate its resources to other activities, enough factors to deny the request of investigation? Could the factors be changed? And in this case, would be the Prosecutor obliged to explain new aspects proprio motu? How does the Court will ensure the legal security of the Prosecutor at the time of preparing the request for authorization of an investigation?

We are confronted by legal issues of constitutional importance ${ }^{\text {108 }}$ which necessarily require a nuanced answer. I have considered that extra-legal factors do not have a place under Article 53 (I) (c), but the Pre-Trial Chamber II has used it and it is logical that we have some doubts, and consequences which are currently unknown as well. Nonetheless, this decision will have repercussion in the reluctance of some States to cooperate with the International Criminal Court.

It is not surprising that appeal claims and other procedural reactions have appeared. On 7 June 20I9, the Office of the Prosecutor made a request for leave to appeal this decision of the Pre-Trial Chamber $\mathrm{II}^{\circ \circ}$; on so June 2org, the Victims filed a request for leave to appeal the Decision before Pre-Trial Chamber $\mathrm{II}^{\text {}}$, and a notice of appeal of the

${ }^{107}$ As it has so far been the case that the Prosecutor when he or she has considered that crimes within the jurisdiction of the Court were committed, the cases were admissible and the gravity of the crimes and the interests of victims has led him or her to the conclusion that the investigation would serve the interests of justice.

${ }_{108}$ This is the adjective used by the Prosecutor herself in relation to some of this doubts, see ICC-02/1734, 7 June 20I9, paragraph I8,

${ }^{\circ} 9$ ICC-02/17-34, 7 June 2019, Public Request for Leave to Appeal the "Decision Pursuant to Article I5 of the Rome Statute on the Authorisation of an Investigation into the Situation in the Islamic Republic of Afghanistan"

по ICC-02/I7-37, ro June 2019, Public with Confidential Annex I, Victim's request for leave to appeal the 
Decision before Appeal Chamber" . In addition, legal representatives of other victims filed two separate notices of appeal before the Appeals Chamber ${ }^{\text {12. }}$ On 17 September 20r9, PreTrial Chamber II granted in part the request of the Prosecutor and victims for leave to appeal"3 $^{13}$. The Appeals Chamber could clarify the way in which the interests of justice are to be understood in the context of authorizing an investigation. The future of other preliminary examinations may depend on it.

\section{(E) CONCLUSION}

The interests of justice have been used by the Pre-Trial Chamber to deny the authorization requested by the Prosecutor with the intention to open an investigation related to the alleged crimes committed by members of the Afghan National Security Forces, members of the Taliban and affiliated armed groups, members of the USA forces and members of the CIA. This decision has been polemic because the Chamber has overturned the decision of the Prosecutor when the latter has noted that there are not substantial reasons to believe that an investigation would not serve the interests of justice, and when she has followed identical procedures and advanced identical arguments on previous successful occasions.

Likewise, criticisms have now arisen because of the apparently innovative criteria that the Chamber has used and their demonstrably extra-legal character, for example, the duration of the preliminary examination, the information and evidence the Prosecutor has got, the degree of cooperation of States at the Preliminary Examination, factors related with the organizational and financial sustainability of the Court, and simple beliefs or conjectures. These are not the only reasons to contest the decision. This decision of the Pre-Trial Chamber could be considered ultra vires. Furthermore, it is also a decision which does not take into account the restorative interest of the victims and has denied them the possibility to become a beneficiary of the assistance programs of the Trust Fund for

\footnotetext{
"Decision Pursuant to Article 15 of the Rome Statute on the Authorisation of an Investigation into the Situation in the Islamic Republic of Afghanistan".

III ICC-o2/17-36, Io June 20I9, Public with Confidential Annex I, Victim's Notice of Appeal of the "Decision Pursuant to Article i5 of the Rome Statute on the Authorisation of an Investigation into the Situation in the Islamic Republic of Afghanistan".

112 ICC-02/17-38, го June 2019, Legal Representatives of Victims, 'Victims' Notice of Appeal of the "Decision Pursuant to Article i5 of the Rome Statute on the Authorisation of an Investigation into the Situation in the Islamic Republic of Afghanistan"; ICC-02/07-36.ro June 2019, Legal Representatives of Victims, 'Victims' Notice of Appeal of the "Decision Pursuant Article i5 of the Rome Statute on the Authorisation of an Investigation into the Situation in the Islamic Republic of Afghanistan,"; ICC-02/17-40Corr.. I2 June 20I9, Legal Representatives of Victims, "Corrected version of the Notice of appeal against the "Decision Pursuant to Article 15 of the Rome Statue on the Authorisation of an Investigation into the Situation in the Islamic Republic of Afghanistan" (ICC-02/17-33)'.

"13 ICC-02/17-62, I7 September 2019, Decision on the Prosecutor and Victims' Requests for Leave to Appeal the 'Decision Pursuant to Article i5 of the Rome Statute on the Authorisation of an Investigation into the Situation in the Islamic Republic of Afghanistan'.
} 
Victims.

It is evident to most commentators that this was not a wise decision. The message which this decision sends to States is clear: Do not collaborate and the International Criminal Court will not investigate the core crimes committed in your territory or by your nationals. If the credibility of the Court was in doubt before it, and if the future of the Court was uncertain, now is possible that the Pre-Trial Chamber has facilitated its own demise.

For the sake of the Court, criminal justice, human rights, and, above all, victims, I hope the Appeals Chamber puts things in their place. Is that too much to ask? 